\title{
Profile of Hiperdia patients in the municipality of Barra Bonita, Sao Paulo state
}

\section{Perfil de pacientes do Hiperdia de Barra Bonita - SP}

\author{
Camila Gimenes, Thalita Maximo Lopes Tinoco, Alberto de Vitta, Eduardo Aguilar Arca, \\ Bruna Varanda Pessoa-Santos, Silvia Regina Barrile*
}

Universidade do Sagrado Coração, (USC), Bauru, SP, Brazil

\begin{abstract}
Introduction: The "Hiperdia System" sets goals and guidelines to expand prevention, diagnosis, treatment and control of Diabetes Mellitus and Hypertension. Knowing the epidemiological characteristics of the population is important to strengthen public health programs. Objective: The objective of the study was to describe the sociodemographic profile, risk factors and complications of hypertensive, diabetic and hypertensive diabetic people registered in the HiperDia system of the Ministry of Health of the Basic Health Units (Unidades Básicas de Saúde - UBS) in Barra Bonita, São Paulo State. Methods: This is a descriptive cross-sectional study, which used 113 medical records of diabetic and hypertensive patients as a data source for information about gender, age, race, education, marital status, body mass index (BMI), family history, smoking, sedentarism, acute myocardial infarction, stroke, kidney disease, amputation and diabetic foot. Descriptive statistics were used. Results: As a result, the epidemiological profile of patients registered in the HiperDia system was characterized by: a mean age of 57.3 years; $61.9 \%$ women, $82.1 \%$ Caucasians, $66.4 \%$ with education level up to incomplete primary education, $48.5 \%$ lived with partners and children, $19.5 \%$ were smokers, $51.4 \%$ were sedentary, $44.3 \%$ were overweight and obese and $69 \%$ had a diagnosis of hypertension and diabetes. Conclusion: The results were relevant allowing professionals and health managers to institute preventive programs to intervene in the risk factors involved in the genesis and complications of hypertension and diabetes.
\end{abstract}

Keywords: Diabetes Mellitus. Hypertension. Epidemiology. Risk Factors. Complications.

*CG: PhD, e-mail: professoracamilagimenes@gmail.com

TMLT: BS, e-mail: thalitamaximo@msn.com

AV: PhD, e-mail: albvitta@yahoo.com.br

EAA: PhD, e-mail: eduardo.arca@usc.br

BVPS: PhD, e-mail: brunavpessoa@gmail.com

SRB: PhD, e-mail: srbarrile@gmail.com 


\section{Resumo}

Introdução: O Sistema Hiperdia estabelece metas e diretrizes para ampliar ações de prevenção, diagnóstico, tratamento e controle do Diabetes Mellitus e Hipertensão Arterial. Conhecer as características epidemiológicas da população é importante para fortalecer programas de saúde pública. Objetivo: O objetivo do estudo foi descrever o perfil sociodemográfico, fatores de risco e complicações dos hipertensos, diabéticos e hipertensos diabéticos cadastrados no sistema HiperDia do Ministério da Saúde das Unidades Básicas de Saúde (UBS) do município de Barra Bonita, São Paulo. Métodos: Trata-se de um estudo transversal descritivo, utilizando como fonte de dados 113 prontuários dos diabéticos e hipertensos, dos quais foram coletadas informações sobre: sexo, idade, cor da pele, escolaridade, situação conjugal, índice de massa corporal (IMC), antecedentes familiares, tabagismo, sedentarismo, infarto agudo do miocárdio, AVE, doença renal, pé diabético e amputação. Foi utilizada estatística descritiva. Resultados: Como resultados notou-se que o perfil epidemiológico dos pacientes cadastrados no Sistema HiperDia foi caracterizado por: média de idade de 57,3 anos, 61,9\% de mulheres, 82,1\% de indivíduos da raça branca; 66,4\% com escolaridade até o fundamental incompleto e 48,5\% convivia com companheiros e filhos; 19,5\% tabagistas; 51,4\% sedentários e 44,3\% sobrepesos e obesos e 69\% apresentavam diagnóstico de hipertensão e diabetes. Conclusão: Os resultados se mostraram relevantes no sentido de permitir que os profissionais e gestores em saúde possam instituir programas preventivos visando intervir nos fatores de risco envolvidos com a gênese e complicações da HAS e do DM.

Palavras-chave: Diabetes Mellitus. Hipertensão. Epidemiologia. Fatores de Risco. Complicações.

\section{Introduction}

The chronic non-communicable diseases (NCDs) represent one of the biggest changes in world public health in the last decades (1), becoming the main priority in the health area in Brazil. In 2007, about $72 \%$ of the deaths were attributed to these diseases (2). Among the NCDs, the systemic arterial hypertension (SAH) and the diabetes mellitus (DM) are considered the main risk factors for the development of heart diseases, such as the acute myocardial infarction (AMI) and the stroke (EVA), besides the chronic kidney disease $(1,3)$.

According to the World Health Organization (WHO), in 2010, the estimate in adults of the prevalence of DM was of 6.4\%, corresponding to 285 million people. Data of the TI Department of the Unified Health System (4), referring to the year 2012, point to a vertiginous increase in adults (above the age of 35 years), with a prevalence of $11.7 \%$ of diabetic people in Brazil. In accordance with data of the International Diabetes Federation (5), Brazil is in the fourth position among the countries with a bigger prevalence of DM, presenting 13.4 million people with the disease.

The SAH is present in $69 \%$ of the patients with AMI, $77 \%$ of the stroke (EVA), $74 \%$ in chronic heart failure (CHF) and $60 \%$ with peripheral artery disease (1). Studies on the SAH in Brazilian cities in last the 20 years pointed to a prevalence above $30 \%$ of the population, among these cities we find São Jose do Rio Preto (SP) and Nobres (MT). Considering MAP values $\geq 140 / 90 \mathrm{mmHg}$, studies found prevalence above $50 \%$ in the age group from 60 to 69 years and $75 \%$ above 70 years old $(6,7)$.

Intending to minimize this situation, a Reorganization Plan of SAH and DM Care, called HiperDia, was created in Brazil, in 2002. Its function is to monitor patients taken care of and registered in the Family Health Strategy (FHS), part of the Unified Health System (SUS), and to raise information for the distribution of medicine among these patients (8). This system also sets goals and guidelines to expand actions of prevention, diagnosis, treatment and control of several risk factors of these pathologies (9).

Personal and familiar history, smoking, obesity and sedentarism are also considered risk factors of SAH and DM $(10,11)$. On the other hand, the modification in the life style, such as an appropriate diet, weight control, restriction to smoking, alcohol consumption and the regular practice of physical exercises contribute to the control of these diseases` risk factors (12).

Therefore, the present study aimed to describe the sociodemographic profile, the risk factors and the complications of the hypertensive, diabetic and hypertensive diabetic registered in the HiperDia system of the Ministry of Health of the Basic Health Units (UBS) of the municipality of Barra Bonita, São Paulo. 


\section{Methods}

It is a descriptive cross-sectional study, using data of the medical records of the diabetic and hypertensive patients, users of the Hiperdia in the UBS of the municipality of Barra Bonita, São Paulo State (Brazil). The Research Ethics Committee of the Universidade do Sagrado Coração approved this study (n.870.011 on 10/29/14).

The subjects were diabetic and hypertensive users, registered in the HiperDia system of the five UBS of the municipality (Vila Habitacional, Health Center, Cohab, Dream Ours and Vila Correa). We analyzed medical records of the HiperDia regarding the period from January to June 2013. The medical records that were incomplete or had wrong data were excluded.

The data collection instrument was a pre-coded questionnaire, elaborated from the registration form of the HiperDia system, following the stratifications and classifications of the form. The independent variables included in the analysis were: gender (male, female); age (20 to 35,36 to 59 and 60 years or more); skin color, classified in accordance with the patient's perception (Caucasian, black, yellow, brown); education (illiterate, primary school incomplete, primary school complete, secondary school incomplete, secondary school complete and higher education complete); marital status (with a partner, without a partner, lives alone); body mass index (BMI), according to the classification of the World Health Organization (WHO, 1995) in normal weight (BMI $\geq 18.5 \mathrm{~kg} / \mathrm{m} 2$ and $<25 \mathrm{~kg} / \mathrm{m} 2$ ), overweight (BMI $\geq 25 \mathrm{~kg} / \mathrm{m} 2$ and $<30 \mathrm{~kg} / \mathrm{m} 2$ ) and obesity (IMC $\geq$ $30 \mathrm{~kg} / \mathrm{m} 2$ ); measure of the abdominal circumference $(102 \mathrm{~cm}$ and $88 \mathrm{~cm}$ considered as superior limits of $\mathrm{AC}$ in the male and female, respectively in accordance with the Brazilian Society of Diabetes, 2007); presence of hypertension, diabetes, family history, smoking (the information in the registration form of the HiperDia comprises data on smoking only at the moment of the registration, it doesn't consider previous smoking), sedentarism, acute myocardium infarction, another heart disease, EVA, kidney disease, diabetic foot and amputation for diabetes, categorized as yes and not.

With the totality of the data collected, we carried out the codification of the instruments and the construction of the database on the Microsoft Office Excel, version 2013. After that, we carried out the stratification and categorization of the variables collected. For the analysis of the data, a descriptive statistics was used, and the values were expressed in absolute frequency (n) and relative frequency (\%).

\section{Results}

We obtained information of the database of the HiperDia System, centralized in the City Health Department of the municipality of Barra Bonita. In this database, there were 3.456 patients registered; however, they were not updated and had incomplete data. Therefore, we studied 113 patients who were registered in the System based on the data of the first semester of 2013.

The mean age was $57.3 \pm 14.6$ years, and eighty-two individuals $(72.6 \%)$ presented an age equal or superior to 50 years old. The individuals were distributed according to the diagnosis and the data found in table 1.

It is possible to observe the predominance of female, Caucasian individuals, with education up to the elementary school incomplete and living with partners and children. Eighteen individuals were of the black race or medium brown and between these $83.3 \%$ presented diagnosis of HAS and $66.6 \%$ DM diagnosis.

Table 1 - Distribution of the individuals according to the diagnosis (To be continued)

\begin{tabular}{|c|c|c|c|c|}
\hline & & SAH & DM & SAH/DM \\
\hline & & N (\%) & N (\%) & N (\%) \\
\hline \multirow[t]{2}{*}{ Gender } & Male & $7(6.3)$ & 10 & $\begin{array}{cc}8) & 26 \\
& (23.0)\end{array}$ \\
\hline & Female & $18(15.9)$ & $11(9.7)$ & $41(36.3)$ \\
\hline \multirow[t]{3}{*}{ Age } & $\begin{array}{c}20 \text { to } 35 \\
\text { years }\end{array}$ & $3(2.7)$ & $3(2.7)$ & $4(3.5)$ \\
\hline & $\begin{array}{c}36 \text { to } 59 \\
\text { years }\end{array}$ & $10(8.8)$ & $12(10.6)$ & $31(27.4)$ \\
\hline & $\begin{array}{l}60 \text { years or } \\
\text { more }\end{array}$ & $12(10.6)$ & $6(5.4)$ & $32(28.3)$ \\
\hline \multirow[t]{4}{*}{ Race } & Caucasian & $19(16.7)$ & 18 (15.9) & $56(49.5)$ \\
\hline & Black & $3(2.7)$ & $0(0.0)$ & $3(2.7)$ \\
\hline & Yellow & $0(0.0)$ & $0(0.0)$ & $2(1.8)$ \\
\hline & Brown & $3(2.7)$ & $3(2.7)$ & $6(5.3)$ \\
\hline \multirow[t]{5}{*}{ Education } & Illiterate & $2(1.8)$ & $1(0.9)$ & $6(5.3)$ \\
\hline & Literate & $2(1.8)$ & $1(0.9)$ & $13(11.5)$ \\
\hline & $\begin{array}{c}\text { Primary } \\
\text { school } \\
\text { incomplete }\end{array}$ & $10(8.8)$ & $8(7.1)$ & 32 (28.3) \\
\hline & $\begin{array}{c}\text { Primary } \\
\text { school } \\
\text { complete }\end{array}$ & $8(7.1)$ & $4(3.5)$ & $7(6.2)$ \\
\hline & $\begin{array}{l}\text { Secondary } \\
\text { school } \\
\text { incomplete }\end{array}$ & $0(0.0)$ & $1(0.9)$ & $3(2.7)$ \\
\hline
\end{tabular}


Table 1 - Distribution of the individuals according to the diagnosis (Conclusion)

\begin{tabular}{|c|c|c|c|c|}
\hline & & SAH & DM & SAH/DM \\
\hline & & N (\%) & N (\%) & N (\%) \\
\hline & $\begin{array}{l}\text { Secondary } \\
\text { school } \\
\text { complete }\end{array}$ & $3(2.7)$ & $4(3.5)$ & $5(4.4)$ \\
\hline & $\begin{array}{l}\text { Higher } \\
\text { education } \\
\text { incomplete }\end{array}$ & $0(0.0)$ & $2(1.8)$ & $0(0.0)$ \\
\hline & $\begin{array}{l}\text { Higher } \\
\text { education } \\
\text { complete }\end{array}$ & $0(0.0)$ & $0(0.0)$ & $1(0.9)$ \\
\hline \multirow{6}{*}{$\begin{array}{l}\text { Marital } \\
\text { status } \\
\text { - lives } \\
\text { with: }\end{array}$} & partner and child & Id $\begin{array}{c}10 \\
(8.7)\end{array}$ & $12(10.6)$ & $33(29.2)$ \\
\hline & $\begin{array}{l}\text { partner with } \\
\text { marital ties and } \\
\text { without children }\end{array}$ & $\begin{array}{c}4 \\
(3.5)\end{array}$ & $4(3.5)$ & $6(5.3)$ \\
\hline & $\begin{array}{l}\text { partner, children } \\
\text { and/or other } \\
\text { family members }\end{array}$ & $\begin{array}{c}1 \\
(0.9)\end{array}$ & $2(1.8)$ & $9(8.0)$ \\
\hline & $\begin{array}{l}\text { family members, } \\
\text { without partner }\end{array}$ & $\begin{array}{lc}\text { s, } & 6 \\
r & (5.3)\end{array}$ & $1(0.9)$ & $15(13.3)$ \\
\hline & $\begin{array}{l}\text { other people, } \\
\text { without } \\
\text { consanguineous } \\
\text { and/or marital } \\
\text { ties }\end{array}$ & $\begin{array}{c}1 \\
(0.9)\end{array}$ & $2(1.8)$ & $1(0.9)$ \\
\hline & Lives alone & $\begin{array}{c}3 \\
(2.7)\end{array}$ & $0(0.00)$ & $3(2.7)$ \\
\hline
\end{tabular}

Note: SAH: systemic arterial hypertension; DM: diabetes mellitus; SAH/DM: systemic arterial hypertension and diabetes mellitus.

All users took anti-hypertensive medicine, with mean values of systolic blood pressure (SBP) of 108 $\pm 44 \mathrm{mmHg}$ and diastolic blood pressure (DBP) of $69 \pm 27 \mathrm{~mm} \mathrm{Hg}$, and, regarding the value of capillary glycaemia, $69 \%$ presented a value out of normality.

Among them, eight individuals $(10.3 \%)$ did not have a diagnosis of DM, but only SAH. The others are diabetic, which suggests they are not controlled since the glycaemia levels are high (13).

The patients' mean weight was $76.6 \pm 16.6 \mathrm{~kg}$, the mean height was $1.62 \pm 9.2 \mathrm{~m}$ and the mean BMI was $29.8 \pm 6.2 \mathrm{~kg} / \mathrm{m}^{2}$ in women and $28.4 \pm 5.1 \mathrm{~kg} /$ $\mathrm{m}^{2}$ in men. Regarding the abdominal circumference measure (AC), $95.7 \%$ of the women and $72.1 \%$ of the men presented AC above normal. The AC mean was $102 \pm 14 \mathrm{~cm}$ in women and $101 \pm 12 \mathrm{~cm}$ in men.

The risk factors and the complications presented by users, according to the diagnosis, are on Table 2. It is possible to observe that most patients did not present Family history nor complications, $19.5 \%$ are smokers, $51.4 \%$ sedentary and $44.3 \%$ are overweight and obese.
Table 2 - Risk factors and complications of individuals according to the diagnosis

\begin{tabular}{lcccc}
\hline & & AHS & DM & AHS/DM \\
Risk factors & & N (\%) & N (\%) & N (\%) \\
\hline Family history & yes & $9(8.0)$ & $10(8.8)$ & $28(24.8)$ \\
& no & $16(14.2)$ & $11(9.7)$ & $39(34.5)$ \\
Smoking & yes & $7(6.2)$ & $5(4.4)$ & $10(8.8)$ \\
& no & $18(15.9)$ & $16(14.2)$ & $57(50.5)$ \\
Sedentarism & yes & $14(12.4)$ & $16(14.2)$ & $28(24.8)$ \\
& no & $11(9.7)$ & $5(4.4)$ & $39(34.5)$ \\
Overweight/obesity & yes & $13(11.5)$ & $9(8.0)$ & $28(24.8)$ \\
& no & $12(10.6)$ & $12(10.6)$ & $39(34.5)$ \\
\hline Complications & & & & \\
\hline AMl & yes & $2(1.8)$ & $5(4.4)$ & $6(5.3)$ \\
& no & $23(20.4)$ & $16(14.2)$ & $61(54.0)$ \\
CAD & yes & $2(1.8)$ & $2(1.8)$ & $2(1.8)$ \\
& no & $23(20.4)$ & $19(16.8)$ & $65(57.4)$ \\
EVA & yes & $4(3.5)$ & $1(0.9)$ & $8(7.1)$ \\
& no & $21(18.6)$ & $20(17.7)$ & $59(52.2)$ \\
Diabetic foot & yes & $1(0.9)$ & $1(0.9)$ & $8(7.1)$ \\
& no & $24(21.2)$ & $20(17.7)$ & $59(52.2)$ \\
Amputation & yes & $0(0.0)$ & $0(0.0)$ & $1(0.9)$ \\
Kidney disease & no & $25(22.1)$ & $21(18.6)$ & $66(58.4)$ \\
& yes & $2(1.8)$ & $2(1.8)$ & $11(9.7)$ \\
& no & $23(20.4)$ & $19(16.7)$ & $56(49.6)$ \\
\hline
\end{tabular}

Note: SAH: systemic arterial hypertension; DM: diabetes mellitus; $\mathrm{SAH} /$ DM: systemic arterial hypertension and diabetes mellitus; IAM: acute myocardium infarction; CAD: coronary artery disease; EVA: stroke.

\section{Discussion}

We studied 113 users, who were registered in 2013 in the HiperDia System of the municipality of Barra Bonita, State of São Paulo, representing 0.55\% of the adult population of the municipality, in accordance with the data of the Brazilian Institute of Geography and Statistics (14). Regarding the amount of patients registered, the number of users included in the study was small, since the forms of the other patients were not completely filled. The studies of Oliveira and Jardim et Leal also showed a high number of forms missing basic information for the 
evaluation of the health condition of the diabetic and hypertensive $(15,16)$.

From the total of the users analyzed, $81.4 \%$ presented a diagnosis of SAH and $59.3 \%$ of both SAH and DM. In the same direction, Lima et al. (17) noticed that, in their study $69.2 \%$ were hypertensive and $26.1 \%$ were diabetic hypertensive. It is known that the individual, who presents one of the pathologies mentioned, has a greater probability of developing the other one (1). As the SAH is associated with a higher degree of insulin resistance and the antihypertensive medicine can aggravate this condition, the hypertensive becomes more susceptible to develop diabetes (18).

A total of $72.6 \%$ of the analyzed individuals presented an age equal or superior to 50 years old. It is known that there is a directly proportional relation between the age and the development of chronic-degenerative diseases: the higher the age, the greater the possibility of developing cardiovascular complications (19).

In the present study, it is possible to observe a predominance of the female gender (62\%). Corroborating with the results, Miranzi et al. (20) affirmed that this can be associated with the biggest amount of women in the world population. Zaitune et al. (21) reported women can have a greater probability of developing SAH and/or DM as they normally present a better perception of the diseases due to self-care and for searching more medical assistance than men.

Out of the total of individuals, 93 were Caucasians. Eighteen individuals were black or and, among these, $83.3 \%$ presented a diagnosis of SAH and $66.6 \%$ presented a diagnosis of DM. Ferreira and Ferreira (8) explain this high prevalence of pathologies among the black and brown individuals is due to ethical or socioeconomical factors presented by this population.

Studies show the level of education of the patients of the HiperDia can be in its majority considered low, and suggest the social inequality in the presence of chronic conditions. To know the level of education of these individuals may contribute to the planning of educational activities for the patient's and their families` integral care (22 -24). We proved the findings of the studies as, in our study, we found $44.3 \%$ of the patients with an incomplete basic education.

Regarding the familiar situation, $94.7 \%$ of the patients lived with other people, which corroborates with the study of Ferreira and Ferreira (8), in which $90 \%$ of the individuals did not live alone. It is known that there is a narrow association of the treatment success with the familiar support, and that, in the case of the diabetic patients, the family collaborates with a better glycemic control (25).

The BMI of women and men characterized overweight. The excess of body mass is a predisposing factor for the $\mathrm{SAH}$, and can be responsible for between 20 and $30 \%$ of the cases. It is known that $75 \%$ of men and $65 \%$ of women present SAH directly associated with overweight and obesity (26). Obesity is commonly associated with DM2. The reduction of weight with a hypo caloric diet increases the tolerance to glucose and sensitivity to insulin, and the practice of regular exercises increases the action of the insulin (27).

According to the criteria of the VI Brazilian Guidelines on Hypertension (26), 95.7\% of women and $72.1 \%$ of men of the present study presented an inadequate $\mathrm{AC}$ and, consequently, an increased cardiovascular risk. Studies were developed and the evidences of an association of the abdominal obesity with a bigger prevalence of morbidities are being confirmed. The android fat distribution, which is a characteristic of central or abdominal obesity, has been more strongly associated with the bigger prevalence of DM, cardiovascular diseases and SAH (28 - 30).

The risk factors that determine and/or influence the development of the SAH and the DM are innumerable. Some are inherent to the individual (age, gender and race) and others are related to the life style (smoking, sedentarism, obesity). In accordance with the literature, the family histories are considered relevant factors for the development of such diseases. Freitas and Sherer (31) affirmed the family history is a risk factor that cannot be medicated and, therefore, its fast recognition is essential for the analysis of individuals in relation to cardiovascular risks. In the present study, $41.6 \%$ of the patients presented a family history of SAH and/or DM.

According to the data of the National Institute of Cancer, smoking is considered the main preventable cause of death, and it duplicates the risk of development of cardiovascular diseases; $30 \%$ of the cases are attributed to the number of cigarettes smoked per day (32). Studies show a greater variation and elevation of the arterial pressure in the hypertensive smokers compared to the nonsmokers (33). In our studied population, $19.4 \%$ were smokers. Miranzi et al. (20) observed similar results, they observed that $19.4 \%$ of the hypertensive were smokers, among who, $66.7 \%$ were women. Other Brazilian studies also presented similar results $(34,35)$. 
Currently, the population presents very bad life habits (inadequate feeding, obesity and sedentarism), which favors the high incidence and prevalence of DM and SAH $(36,37)$. Moreira et al. (38) claim that the overweight and the sedentarism are constantly found in studies on cardiovascular risk factors, since they are consequences of a consumerist society, in which feeding occurs in a fast and practical way and the daily activities demand minimums efforts to be executed. In our study, it was observed that $51.3 \%$ of the patients are sedentary and $44.3 \%$ present overweight or obesity. The lack of physical activity is estimated to be annually responsible for $10 \%$ to $16 \%$ of the DM cases and $22 \%$ of the ischemic illnesses (39).

The presence of complications in these patients can be associated with the lack of control of the SAH and of the DM regarding the EVA (11.5\%), the kidney disease (13.3\%) and, particularly, the AMI (11.5\%). This makes us reflect about the association of the cares of the Family Health Units' team and the PSF that will have to be intensified during the monitoring of these patients. Freire et al. (40) assessed 17 individuals with DM2 of the PSF from Presidente Prudente (SP) and reported the patients need more information and programs to prevent DM complications, predisposing alterations to amputations and other complications. Ferreira and Ferreira (8) observed in their study that the AMI (81.3\%), the EVA (8\%) and the kidney disease (9.9\%) are the complications that are more often observed in patients with DM2. In 2004, Toscano (36) observed that $33 \%$ of the diagnosis of chronic kidney failure in Americans was attributed primarily to the DM, in which half were due to DM2.

In our study, one of the complications, the diabetic foot, was present in $7.1 \%$ of the patients who presented SAH and DM. According to Vieira-Santos et al. (41), the diabetic foot represented $9 \%$ of a sample of 1,374 diabetic people cared for in the Family Health Units of the municipality of Recife/PE, Brazil. In their study, Nunes et al. (42) observed that $55 \%$ of the diabetic hospitalized in the State of Sergipe, Brazil, with ulcerated feet, evolved into some type of amputation of the lower limbs, and 59\% of them represented female individuals with an age of 61 years old.

The analysis of the data of the HiperDia of the municipality of Barra Bonita/SP showed that, when the patients arrived at the Basic Health Units (UBS), they already presented associated complications and a likely unsatisfactory metabolic control. Therefore, a bigger attention of the health professionals in relation to preventive measures is necessary.

It is important to highlight that the data collected in the HiperDia System cannot be controlled by the researcher, since they are filled by the employees of the UBS, with eventual typing mistakes, imperfections in the system that difficult the exportation of data and the lack of information. Moreover, when the covering of the HiperDia System is analyzed, it is verified that the municipality has presented difficulties in standardizing the ideal estimate of DM prevalence because many patients' registration is outdated or they do not look for the public service. Therefore, we suggest the development of future studies that approach, in a deeper way, the possible reasons that can justify such facts.

\section{Conclusion}

The epidemiologic profile of the patients registered in the HiperDia System of the municipality of Barra Bonita/SP was characterized by: A mean age of 57.3 years, a predominance of the female gender, Caucasians; a low level of education; $19.5 \%$ smokers; most sedentary and $44.3 \%$ overweight and obese. More than the half of the patients presented a concomitant diagnosis of SAH and DM.

Epidemiological studies must be stimulated as they show the importance of establishing public health programs that aim to fortify changes in the life style, fighting the risk factors involved with the genesis and complications of the SAH and the DM. Thus, this type of study allows the physiotherapist to identify and follow problems that need a continuous attention and, after that, propose promotional, preventive, healing and rehabilitating actions, that is, a performance to an integral health, in contrast to the traditional and medicalized method, which is fragmented, hospitalcentered and based on the social exclusion.

\section{Acknowledgments}

We thank Dr Sérgio, Director of the Health Department, who authorized this study; Kátia Camila Altrin, who collaborated with the data collection; and Márcia Cardoso, who explained the functioning of the HiperDia system. 


\section{References}

1. Souza CS, Stein AT, Bastos GAN, Pellanda LC. Controle da pressão arterial em hipertensos do programa Hiperdia: Estudo de Base territorial. Arq Bras Cardiol. 2004;102:571-8.

2. Schmidt MI, Duncan BB, Azevedo e Silva G, Menezes AM, Monteiro CA, Barreto SM, et al. Doenças crônicas não transmissíveis no Brasil: carga e desafios atuais. In: Saúde no Brasil. The Lancet. 2001 May:61-74. [cited 2013 Mar 22]. Available from: http://www. abc.org.br/IMG/pdf/doc-574.pdf.

3. Faerstein E, Chor D, Werneck GL, Lopes CDES, Kaplan G. Race and perceived racism, education, and hypertension among Brazilian civil servants: the Pró-Saúde Study. Rev Bras Epidemiol. 2014;17(Suppl 2):81-7.

4. Datasus - Departamento de Informática do SUS / Ministério da Saúde. Ministério da Saúde. Secretaria de Vigilância em Saúde (SVS): Vigilância de fatores de risco e proteção para doenças crônicas por inquérito telefônico (VIGITEL). 2014 [cited 2014 Nov 11]. Available from: http://tinyurl.com/zw2kb97.

5. International Diabetes Federation. IDF Diabetes Atlas. 5th ed. Brussels (Belgium):International Diabetes Federation; 2012.

6. Cesarino CB, Cipullo JP, Martin JFV, Cirorlia LA, Godoy MRP, Cordeiro, JA et al. Prevalência e fatores sociodemográficos em hipertensos de São José do Rio Preto. Arq Bras Cardiol. 2008;91:31-5.

7. Rosário TM, Scala LCNS, França GVA, Pereira MRG, Jardim PCBV. Prevalência, controle e tratamento da hipertensão arterial sistêmica em Nobres, MT. Arq Bras Cardiol. 2009;93(6):672-8.

8. Ferreira CLRA, Ferreira MG. Características epidemiológicas de pacientes diabéticos da rede pública de saúde - análise a partir do sistema HiperDia. Arq Bras Endocrinol Metab. 2009;53(1):80-6.

9. Ministério da Saúde. Hiperdia - Sistema de Cadastramento e Acompanhamento de Hipertensos e Diabéticos - Manual de Operação. Rio de Janeiro; 2002. Portuguese.

10. Aurichio TR, Rebelatto JR, Castro AP. Obesidade em idosos do Município de São Carlos, SP e sua associação com diabetes melito e dor articular. Fisioter Pesqui. 2010;17(2):114-7.
11. Mamtani, R, Lowenfels AB, Sheikh J, Cheema S, Alhamaq A, Matthis SA, et al. Adolescent prediabetes in a high-risk Middle East country: a cross-sectional study. JRSM Open. 2014;5(8):1-5.

12. Chiuve SE, Cook NR, Shay CM, Rexrode KM, Albert CM, Manson JS, et al. Lifestyle-Based Prediction Model for the Prevention of CVD: The Healthy Heart Score. J Am Heart Assoc. 2014;3(6):e000954.

13. Guideline for Management of Postmeal Glucose. Brussels (Belgium) International Diabetes Federation. 2007 [cited 2013 Nov 5]. Available from: http:// tinyurl.com/ykcvx6e.

14. IBGE - Cidades. Instituto Brasileiro de Geografia e Estatística; 2014 [cited 2014 Nov 20]. Available from: http://tinyurl.com/zhamrdo. Portuguese.

15. Oliveira CA. O sistema de informações HIPERDIA em Guarapuava/PR 2002-2004: implantação e qualidade das informações [master's thesis]. Ribeirão Preto (Brazil): Escola de Enfermagem de Ribeirão Preto da Universidade de São Paulo; 2005. Portuguese.

16. Jardim ADI, Leal AMO. Qualidade da informação sobre diabéticos e hipertensos registrada no sistema HIPERDIA em São Carlos - SP, 2002-2005. Physis. 2009;19(2): 405-17.

17. Lima-Silva AE, Adami F, Nakamura FY, Oliveira FR, Gevaerd MS. Metabolismo de gordura durante o exercício físico: mecanismos de regulação. Rev Bras Cineantropom Desempenho Hum. 2006;8(4):106-14.

18. Francisco PMSB, Belon AP, Barros MBA, Carandina $\mathrm{L}$, Alves MCGP, Goldbaum M, et al. Diabetes autoreferido em idosos: prevalência, fatores associados e práticas de controle. Cad Saude Publica. 2010;26(1):175-84.

19. Finotti V, Rizzo E, Freitas GK. Avaliação da qualidade de vida de indivíduos hipertensos submetidos ou não à assistência fisioterapêutica em unidades básicas de saúde no Município de Vila Velha - ES. Vila Velha (Brazil): Faculdade Novo Milênio; 2008. Portuguese.

20. Miranzi SSC, Ferreira FS, Iwamoto HH, Pereira GA, Miranzi MAS. Qualidade de vida de indivíduos com diabetes mellitus e hipertensão acompanhados por uma equipe de saúde da família. Texto Contexto Enferm. 2008;17(4):672-9. 
21. Zaitune MPA, Barros MBA, César CLG, Carandina L, Goldbaum M. Hipertensão Arterial em idosos: prevalência, fatores associados e práticas de controle no município de Campinas, São Paulo, Brasil. Cad Saude Publica. 2006;22(2):285-94.

22. Ministério da Saúde, Secretaria de Vigilância da Saúde, Secretaria de Atenção Básica. Instituto Nacional do Câncer. Inquérito Domiciliar sobre Comportamento de Risco e Morbidade Referida de Doenças e Agravos Não Transmissíveis. Rio de Janeiro: Instituto Nacional de Câncer (INCA); 2004. Portuguese.

23. Theme-Filha MM, Szwarcwald CL, Souza-Júnior PR. Socio-demogaphic characteristics, treatment coverage, and self-rated health of individuals who reported six chronic disease in Brazil, 2003. Cad Saude Publica. 2005;21Suppl:43-53.

24. Barros MBA, César LG, Carandina L, Torre GD. Desigualdades sociais na prevalência de doenças crônicas no Brasil, PNAD 2003. Cienc Saude Coletiva. 2006;11(4):911-26.

25. Caixeta CC. As relações familiares e o processo de adoecimento em diabetes tipo 2 [master's thesis]. Ribeirão Preto (Brazil): Escola de Enfermagem de Ribeirão Preto da Universidade de São Paulo; 2007. Portuguese.

26. Sociedade Brasileira de Cardiologia/Sociedade Brasileira de Hipertensão/Sociedade Brasileira de Nefrologia. VI Diretrizes Brasileiras de Hipertensão. 2010;95(supl 1):1-51. Portuguese.

27. Negrão CE, Trombetta IC, Tinucci T, Forjaz CLM. O papel do sedentarismo na obesidade. Rev Bras Hipertens. 2000;7(2):149-55.

28. Jung RT. Obesity as a disease. Br Med Bull. 1997;53(2):307-21.

29. Foucan L, Hanley J, Deloumeaux J, Suissa S. Body mass index (BMI) and waist circumference (WC) as screening tools for cardiovascular risk factors in Guadeloupean women. J Clin Epidemiol. 2002;55(10):990-6.

30. Jardim PCVB, Gondim MRP, Monego ET, Moreira HG, Vitorino PVO, Souza WKSB et al. Hipertensão arterial e alguns fatores de risco em uma capital brasileira. Arq Bras Cardiol. 2007;88(4):452-7.

31. Freitas K, Schere F. Perfil nutricional e identificação dos fatores de risco para doenças cardiovasculares. Rev Destaques Academicos. 2010;2(3):59-68.
32. INCA. Instituto Nacional do Câncer [cited 2013 Nov 4]. Available from: http://tinyurl.com/hdpfshg. Portuguese.

33. Ministério da Saúde. Atenção à Saúde do Adulto Hipertensão e Diabetes: Saúde em Casa. 1st ed. Belo Horizonte (Brazil): Secretaria de Estado de Saúde de Minas Gerais; 2006. Portuguese.

34. Pessuto J, Carvalho EC. Fatores de risco em indivíduos com hipertensão arterial. Rev Latino Am Enfermagem. 1998;6(1):33-9.

35. Trindade IS, Heinick G, Machado JR, Ayzemberg H, Formighieri M, Crestani M, et al. Prevalência da Hipertensão Arterial Sistêmica na População Urbana de Passo Fundo (RS). Arq Bras Cardiol. 1998;71(2):127-30.

36. Toscano CM. As campanhas nacionais para detecção das doenças crônicas não-transmissíveis: diabetes e hipertensão arterial. Cienc Saude Coletiva. 2004;9(4):885-95.

37. Longo GS, Neves J, Castro TG, Pedroso MRO, Matos IB. Prevalência e distribuição dos fatores de risco para doenças crônicas não transmissíveis entre adultos da cidade de Lages (SC), sul do Brasil, 2007. Rev Bras Epidemiol. 2011;14(4):698-708.

38. Moreira TMM, Gomes EB, Santos JC. Fatores De Risco Cardiovasculares em Adultos Jovens com Hipertensão Arterial e/ou Diabetes Mellitus. Rev Gaucha Enferm. 2010;31(4):662-9.

39. Centers for Disease Controland Prevention (CDC). Improving nutrition and increasing physical activity. 2003 [cited 2013 Nov 2]. Available from: http:// tinyurl.com/obfd4sa.

40. Freire APCF, Palma MR, Lacombe JCA, Martins RML, Lima RAO, Pacagnelli FL. Implementation of physiotherapeutic shares in the prevention of diabetes complications in a Family Health Strategy. Fisioter Mov. 2015;28(1):69-76.

41. Vieira-Santos ICR, Souza WV, Carvalho EF, Medeiros MCWC, Nóbrega MG, Lima PMS. Prevalência de pé diabético e fatores associados nas unidades de saúde da família da cidade do Recife, Pernambuco, Brasil, em 2005. Cad Saude Publica. 2008;24(12):2861-70. 
42. Nunes MAP, Resende KF, Castro AA, Pitta GBB, Figueiredo LFP, Miranda Jr F. Fatores predisponentes para amputação de membro inferior em pacientes diabéticos internados com pés ulcerados no estado de Sergipe. J Vasc Bras. 2006;5(2):123-30.

Received in 06/02/2015

Recebido em 02/06/2015

Approved in 11/19/2015

Aprovado em 19/11/2015 
